\title{
Cambrian Zawidów granodiorites in the Cadomian Lusatian Massif (Central European Variscides): what do the SHRIMP zircon ages mean?
}

\author{
Dawid BIAŁEK ${ }^{1, *}$, Ryszard KRYZA', Teresa OBERC-DZIEDZIC', Christian PIN² \\ ${ }^{1}$ Institute of Geological Sciences, University of Wrocław, Plac M. Borna 9, 50-204 Wrocław, Poland; dawid.bialek@ing.uni.wroc.pl \\ ${ }^{2}$ Département de Géologie CNRS and Université Blaise Pascal, 5 rue Kessler, F-63038 Clermont-Ferrand Cedex, France \\ * Corresponding author
}

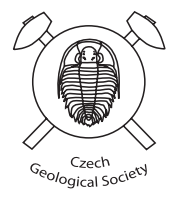

The Lusatian Massif in the Central European Variscides, composed of Upper Neoproterozoic (c. 570 Ma) greywacke intruded by $c .540$ Ma old Cambrian granodiorites (and the somewhat younger Zawidów granodiorites), constitutes a fragment of the Cadomian basement of the Saxo-Thuringian Zone. The Lusatian Massif adheres on the east to the Karkonosze-Izera Massif composed of the $c$. 500 Ma Izera/Rumburk granites related to the Cambro-Ordovician rifting of the Cadomian basement, and narrow belts of micaschists. Trace-element and Sm-Nd isotope data suggest that the source rocks for the Lusatian greywacke, the Zawidów granodiorite and the Izera/Rumburk granite could have been similar, though not the same. The new SHRIMP U-Pb zircon data for the Zawidów granodiorite reveal, apart from the expected c. $540 \mathrm{Ma}$ ages, three other zircon age populations of around $630 \mathrm{Ma}, 600 \mathrm{Ma}$ and $510 \mathrm{Ma}$, the latest being evidently younger than $540 \mathrm{Ma}$ that was considered as the age of the granodiorite magma emplacement. Zircons with ${ }^{206} \mathrm{~Pb} /{ }^{238} \mathrm{U}$ ages around $510 \mathrm{Ma}$, and somewhat older (up to $c .538 \mathrm{Ma}$ ), have also been reported from the Izera granites. This could mean that the granitic plutonism related to the Cadomian orogenic cycle and the Cambro-Ordovician rifting triggered two or more magmatic pulses during at least $c$. $30 \mathrm{My}$. During the prolonged period of igneous activity, the plate-tectonic environment at the Gondwana margin changed from collisional (Cadomian Orogeny), to initial rifting (Cambro-Ordovician).

Keywords: Cadomian orogeny, Cambro-Ordovician rifting, Lusatian granodiorites, Izera/Rumburk granites, SHRIMP zircon dating, Sm-Nd isotopes

Received: 28 October 2013; accepted: 29 October 2014; handling editor: G. Zulauf

\section{Introduction}

The demise of the Ediacaran Cadomian orogeny and the initiation of the Cambro-Ordovician rifting were characterized by intense granitoid magmatism. In the eastern part of the Saxo-thuringian Zone (Fig. 1a) of the Variscan belt occur the Cadomian granitoids of the Lusatian Massif (in SE Germany, SW Poland and N Czech Republic), dated at $540-530 \mathrm{Ma}\left({ }^{207} \mathrm{~Pb} /{ }^{206} \mathrm{~Pb}\right.$ zircon evaporation ages, Kröner et al. 1994; Gehmlich et al. 1997; Tichomirowa 2002). On the other hand, Late Cambrian/Early Ordovician granites are represented by the Izera granites/ orthogneisses, and their local varieties: the Rumburk granite, Kowary and Karkonosze (ortho-)gneisses, all dated at $c$. 500 Ma using various $\mathrm{U}-\mathrm{Pb}$ zircon techniques (Kröner et al. 2001; Oberc-Dziedzic et al. 2009, 2010; Żelaźniewicz et al. 2009). These Cambro-Ordovician granites and orthogneisses form the Izera-Kowary Unit in the Karkonosze-Izera Massif (Fig. 1b; Mazur and Kryza 1996; Mazur et al. 2006).

The field relations show that the Lusatian granodiorites were intruded by the Rumburk granites (Domečka 1970; Opletal et al. 1983). The available age data suggest that the time gap between the emplacement of the older Lusatian granodiorites (540 Ma) and the younger Izera/ Rumburk granites was $c$. 40 My (Kröner et al. 1994, 2001; Gehmlich et al. 1997; Oberc-Dziedzic et al, 2009, 2010; Żelaźniewicz et al. 2009).

In this paper, we present the first SHRIMP U-Pb zircon data for the Zawidów (Lusatian) granodiorite, exposed in the eastern part of the Lusatian Massif. We compare the new ages with available radiometric data for the Lusatian greywacke (Linnemann et al. 2004) and the Izera granites and micaschists (Oberc-Dziedzic et al. 2009, 2010; Żelaźniewicz et al. 2009). Based on the comparison of the published and new petrological, geochemical, isotopic and age data, we address the problem of possible genetic relationship between the Lusatian granodiorites and the Izera/Rumburk granites, and the prospective contribution of deep-seated sources similar to the Lusatian greywackes to their genesis. Finally, we discuss the prolonged, multiphase granitoid magmatic activity, recorded in the Lusatian and Karkonosze-Izera massifs, within the context of changing plate tectonic settings at the northern periphery of Gondwana, from Cadomian convergence to Cambro-Ordovician rifting. 


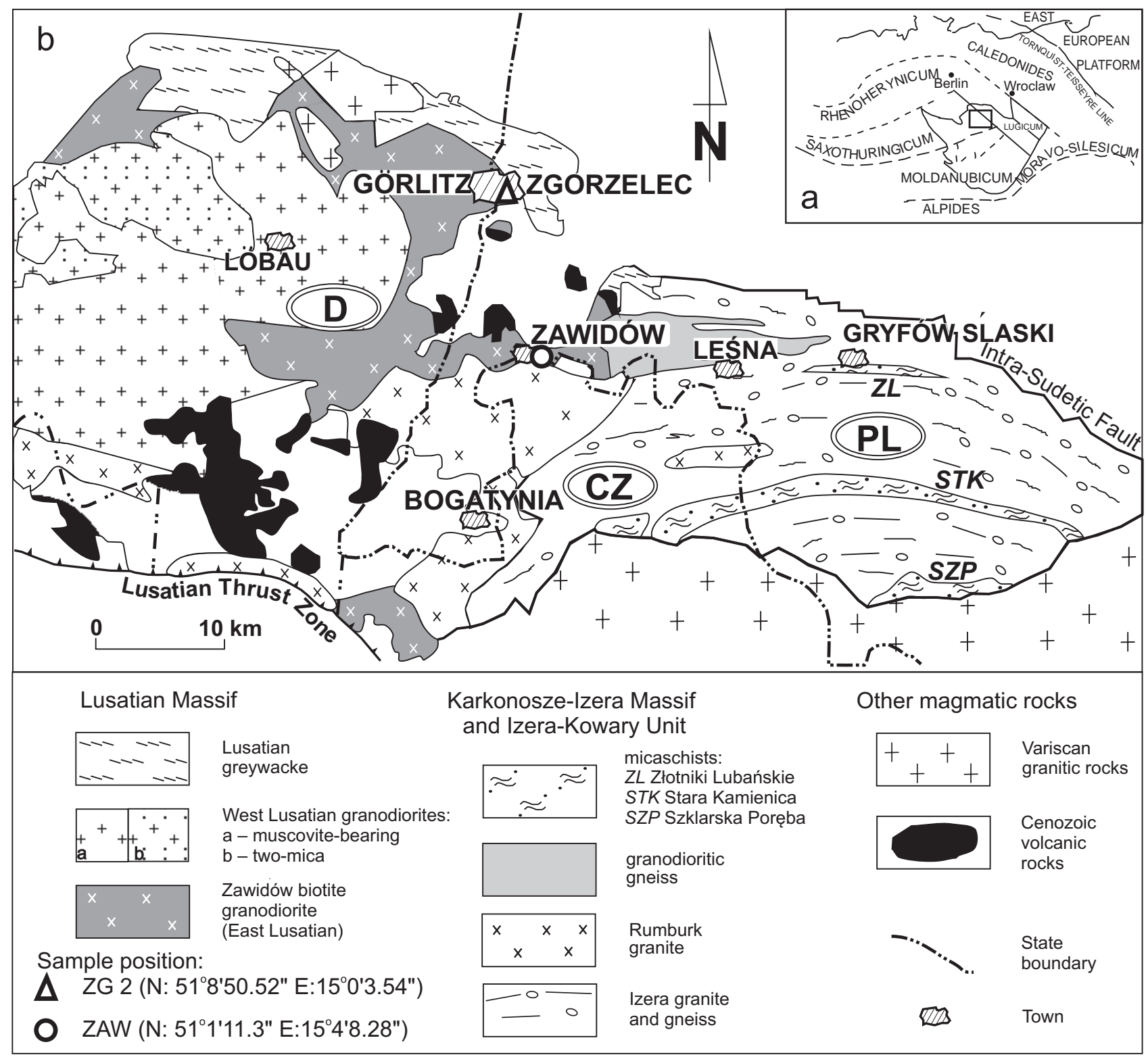

Fig. 1 Simplified geological map of the central part of the Lusatian-Izera Massif (b) and inset showing its position in the Bohemian Massif (a).

\section{Geological setting}

The Lusatian Massif in the eastern Saxo-Thuringian Zone (or Saxothuringicum, sensu Kossmat 1927; Fig. 1a-b) represents a fragment of the Cadomian basement within the Variscan belt. The massif is dominated by a clastic sedimentary sequence, the Lusatian greywacke, c. 570 Ma old (based on SHRIMP zircon dating of syn-sedimentary volcanic tuff layers, Linnemann et al. 2000). The Lusatian greywackes are low-grade turbidites with well-preserved primary sedimentary features of the Bouma sequence (Kemnitz 1998, 2007). The greywackes were intruded by the Lusatian granodiorites, c. 540-530 Ma old $\left({ }^{207} \mathrm{~Pb} /{ }^{206} \mathrm{~Pb}\right.$ evaporation zircon ages, Kröner et al. 1994, 2001; Gehmlich et al. 1997; Linnemann et al. 2000; Tichomirowa 2002). The Lusatian granodiorites show a zonal distribution of compositional types: medium-grained two-mica granodiorite and mediumgrained muscovite-bearing biotite granodiorite occur in the center of the magmatic complex, whereas medium- to coarse-grained biotite granodiorite forms its marginal part. The granodiorite-type succession: 1) the two-mica granodiorite, 2) the muscovite-bearing biotite granodiorite, 3) the biotite granodiorite, was established based on field relationships between the rock varieties, as well as mineralogical and geochemical arguments (Krauss et al. 1992).

The Cadomian basement of the Saxo-Thuringian Zone is overlain by Lower Palaeozoic (meta)sedimentary rocks, separated from the basement by two breaks 
in sedimentation, at c. 540-530 Ma and 500-490 Ma (Linnemann et al. 2007).

The Neoproterozoic-Lower Cambrian rocks of the Lusatian Massif cropping out in the study area, near Zgorzelec, Zawidów and Leśna (Fig. 1b), are represented by the Zawidów granodiorite (biotite granodiorite $=$ East Lusatian or Seidenberger granodiorite) including its deformed varieties - granodiorite gneiss (Kozłowska-Koch 1965; Szałamacha 1970), and by the Lusatian greywacke. The greywacke was intruded and thermally metamorphosed by the Zawidów granodiorite. Contact metamorphic effects in the greywacke include the crystallization of biotite and, probably, cordierite, the latter completely transformed into pinite (Borkowska 1959; Smulikowski 1972). These rather faint effects point to a relatively shallow depth of the granodiorite emplacement.

To the east, the Lusatian Massif is adjacent to the Izera-Kowary Unit (Fig. 1b) of the Karkonosze-Izera Massif (Mazur and Kryza 1996; Mazur and Aleksandrowski 2001; Żelaźniewicz et al. 2011). The IzeraKowary Unit is composed predominantly of granitic orthogneisses (designated by local names, as the Rumburk, Izera, Karkonosze and Kowary granites/orthogneisses) dated at $\sim 500 \mathrm{Ma}$ (U-Pb SHRIMP method, ObercDziedzic et al. 2009, 2010; Żelaźniewicz et al. 2009). The origin of these granites is ascribed to the Late Cambrian/ Early Ordovician rifting of the Cadomian orogen, prior to the formation of the Saxothuringian Basin (Pin et al. 2007).

Three latitudinal schist belts occur within the gneisses of the Izera-Kowary Unit, from $\mathrm{N}$ to $\mathrm{S}$ : the Złotniki Lubańskie, the Stara Kamienica and the Szklarska Poręba belts (Fig. 1b). The boundary between the Lusatian Massif and the Izera-Kowary Unit of the Karkonosze-Izera Massif is defined as an intrusive contact zone (Domečka 1970; Opletal et al. 1983). Rocks considered as equivalents of the Lusatian granodiorite and Lusatian greywacke were found among the Izera gneisses, far away from the main outcrops of these rocks in the west. Based on similar ages (Żelaźniewicz et al. 2004), the granodioritic gneiss in the Izera-Kowary Unit is considered as a deformed equivalent of the Lusatian granodiorite. A metamorphosed equivalent of the Lusatian greywacke can be the Złotniki Lubańskie micaschists (Berg 1935; Kozłowski 1974; Oberc-Dziedzic 1988; Chaloupský et al. 1989). Indeed, the zircon ages from a volcanogenic intercalation in the Złotniki Lubańskie schists (Żelaźniewicz et al. 2009) correspond to those from volcanogenic intercalations in the Lusatian greywacke (Gehmlich et al. 1997; Żelaźniewicz et al. 2003).

The protolith age of the Stara Kamienica and Szklarska Poręba schists is probably Late Cambrian/Early Ordovician, similar to that of the Velká Úpa schists south of the Karkonosze Pluton (Oberc-Dziedzic et al. 2009).
Further details on the structure and evolution of the Karkonosze-Izera Massif can be found in Mazur and Kryza (1996), Mazur and Aleksandrowski (2001), Mazur (2003), Oberc-Dziedzic (2003), Żelaźniewicz et al. (2003), Białek (2003, 2007), and Mierzejewski (2003, 2007).

\section{Previous geochronology}

The depositional age of the Lusatian greywacke was determined on zircons from an intercalated tuff layer (Linnemann et al. 2000): $565 \pm 3 \mathrm{Ma}$ (by the ${ }^{207} \mathrm{~Pb} /{ }^{206} \mathrm{~Pb}$ evaporation method) and $574 \pm 8 \mathrm{Ma}$ (SHRIMP). Kröner et al. (1994) obtained zircon evaporation ${ }^{207} \mathrm{~Pb} /{ }^{206} \mathrm{~Pb}$ ages for the Lusatian granodiorites ranging between $587 \pm 17$ to $542 \pm 9 \mathrm{Ma}$. They inferred either a prolonged ( $\sim 40$ My) magmatic activity or three successive episodes of granodiorite emplacement within the same interval ( 585 , $\sim 563$, $\sim 542 \mathrm{Ma}$ ). Mean ${ }^{207} \mathrm{~Pb} /{ }^{206} \mathrm{~Pb}$ evaporation ages obtained from zircons by Tichomirowa (2002) suggest that the melt formation of the Lusatian granodiorites occurred over a more limited time interval (c. 540-530 Ma). According to Tichomirowa (2002), the ages obtained by Kröner et al. (1994) have to be reconsidered as a mixture of two successive magmatic events: a later, late Cadomian ( 540-530 Ma) that formed the granodiorites, and an earlier ( $580-570 \mathrm{Ma})$, indicated by inherited zircons. Similar age of $541+7 /-8$ Ma was obtained for the Zgorzelec granodiorite (Dörr et al. 2002, ID-TIMS U-Pb, on single, mechanically abraded zircon grains).

The granodioritic gneiss in the western part of the Karkonosze-Izera Massif was dated at $533 \pm 9$ Ma (IDTIMS U-Pb, on single, non-abraded and mechanically abraded zircon grains, Żelaźniewicz et al. 2004).

Sericite pseudomorphs after muscovite in a cataclastic variety of the Zawidów granodiorite yielded an age of $323 \pm 6 \mathrm{Ma}$ (Ar-Ar method, Marheine et al. 2002).

Summing up the published geochronological data, still unresolved remains the question whether the Lusatian granodiorites and the Izera granites/gneisses were produced during a protracted (near?) continuous magmatic activity or rather represent distinct plutonic pulses, separated by relatively short time intervals, during the waning stages of the Cadomian orogeny, passing to the Cambro-Ordovician initial rifting.

\section{Materials and methods}

\subsection{Whole-rock geochemistry}

Two new bulk-rock chemical analyses of undeformed granodiorites from Zawidów (ZAW) and Zgorzelec 
(ZG 2) were performed at Acme Analytical Laboratories (Vancouver, Canada). Major- and trace elements (including REE) were measured using combined ICP-OES and ICP-MS techniques [analytical package 4LITHORES (11+): Major Elements Fusion ICP(WRA)/Trace Elements Fusion ICP/MS(WRA4B2)]. The available data for the Zawidów granodiorite, the Lusatian greywacke and the Izera granites have been plotted using the GCDkit software (Janoušek et al. 2006).

\subsection{Nd isotopes}

For the $\mathrm{Sm}-\mathrm{Nd}$ isotope analyses, the samples were first decomposed by fusion in an induction furnace with $\mathrm{LiBO}_{2}$ as a fluxing agent (Le Fèvre and Pin 2005), and the resulting melt was dissolved in $1.25 \mathrm{M} \mathrm{HCl}$. Then, Sm and Nd were separated from matrix elements and each other by a procedure adapted from Pin and Santos Zalduegui (1997) combining cation-exchange with extraction chromatography techniques. Samarium concentrations were measured with a ${ }^{149} \mathrm{Sm}$-enriched tracer on an upgraded VG54E mass spectrometer in the single collector mode (Clermont-Ferrand), while Nd concentrations and ${ }^{143} \mathrm{Nd} /{ }^{144} \mathrm{Nd}$ isotope ratios were determined concomitantly with a ${ }^{150} \mathrm{Nd}$-enriched tracer and a Triton TIMS machine operated in the static multicollection mode (GIS Laboratory, Nîmes University). Two measurements of the Japan Geological Survey standard JNdi-1 made along with the samples provided ${ }^{143} \mathrm{Nd} /{ }^{144} \mathrm{Nd}$ ratios of $0.512102 \pm 2$ and $0.512099 \pm 3$, respectively, the mean of which corresponds to a value of 0.511843 for the La Jolla standard (Tanaka et al. 2000).

The depleted-mantle model ages are calculated following the single-stage model originally proposed by DePaolo (1981a, b). As it is believed that these ages do not reflect specific geological events, but rather an average crustal residence, it was not found useful to use more elaborate (i.e., two-stage) models.

\subsection{SHRIMP U-Pb dating of zircon}

One of the samples, the Zawidów granodiorite (ZG 2), was selected for SHRIMP zircon dating. Details of the SHRIMP analytical procedure are given in the geochronology section below.

\section{Petrography of the Zawidów granodiorite}

The Zawidów granodiorite is a medium-grained rock characterized by the presence of K-feldspar phenocrysts. It is composed of quartz (32 vol. \%), sodic plagioclase (44\%), K-feldspar (15\%), biotite (8\%) and small amount of muscovite. Accessory phases are titanite, apatite, monazite zircon and opaque.

Plagioclase $\left(\mathrm{An}_{19-1}\right)$ forms subhedral tabular grains showing albite and Carlsbad twinning, normally or reversely zoned. Plagioclase commonly forms clusters of two to three grains together with biotite. Some plagioclase crystals have altered cores, but usually entire grains are altered to a mixture of sericite, quartz and clay minerals.

K-feldspar grains are usually poikilitic, microperthitic and show both Carlsbad and cross-hatched twinning. The largest subhedral crystals contain inclusions of plagioclase, biotite and quartz that, locally, show zonal or, in case of biotite, subparallel arrangement.

Biotite occurs as single flakes or in clusters with muscovite or plagioclase. It shows a distinctive reddish brown color and intense pleochroism. Locally, it is altered to chlorite and muscovite. Inclusions of apatite, zircon and monazite are common.

Muscovite is both primary and secondary, according to the criteria of Zen (1988). The primary muscovite forms larger flakes which, together with quartz, fill the spaces between other minerals or are intergrown with biotite. The secondary muscovite occurs as small flakes in the alteration products of biotite and feldspars.

Quartz forms anhedral interlobate grains, up to $1 \mathrm{~cm}$ across, in the matrix and, also, small inclusions in K-feldspar megacrysts.

Granodiorites exposed near Zgorzelec and Zawidów are cut by shear zones, up to several meters wide, with fabrics varying from typical of undeformed granodiorite, to mylonite. The shear zones experienced fluid migration, as evidenced by sericitization and chloritization of primary minerals. Deformation within these shear zones took place under approximately constant volume (Białek 1999a).

\section{Whole-rock chemical composition}

\subsection{Major elements}

The Zawidów granodiorite contains, in the two newly analyzed samples, 65.4 and 66.9 wt. \% of $\mathrm{SiO}_{2}$. The $\mathrm{K}_{2} \mathrm{O}$ and $\mathrm{Na}_{2} \mathrm{O}$ contents are mutually comparable (3.66 and 3.71 wt. \%, and 3.46 and 3.58 wt. \%, respectively) and much higher than $\mathrm{CaO}$ (1.78 and 2.05 wt. \%). Alumina concentrations are 14.75 and 15.10 wt. \%. The contents of $\mathrm{Fe}_{2} \mathrm{O}_{3}$ (3.82 and 4.34 wt. \%), $\mathrm{MgO}$ (1.28 and 1.56 wt. \%) and $\mathrm{TiO}_{2}(0.57$ and 0.67 wt. \%) vary slightly (Tab. 1$)$.

The granodiorite is peraluminous $(\mathrm{A} / \mathrm{CNK}=1.2$; Tab. 1). The sum of quartz, orthoclase and albite is between $80-95 \%$ of the total CIPW norms, whereas the normative corundum ranges up to $5.3 \%$ (Białek 2007). 
Tab. 1 Major (wt. \%) and trace-element (ppm) whole-rock analyses of the Zawidów granodiorite

\begin{tabular}{|c|c|c|}
\hline SAMPLE & ZAW & ZG 2 \\
\hline $\mathrm{SiO}_{2}$ & 66.90 & 65.40 \\
\hline $\mathrm{TiO}_{2}$ & 0.57 & 0.67 \\
\hline $\mathrm{Al}_{2} \mathrm{O}_{3}$ & 14.75 & 15.10 \\
\hline $\mathrm{Fe}_{2} \mathrm{O}_{3}$ & 3.82 & 4.34 \\
\hline $\mathrm{MnO}$ & 0.05 & 0.06 \\
\hline $\mathrm{MgO}$ & 1.28 & 1.56 \\
\hline $\mathrm{CaO}$ & 1.78 & 2.05 \\
\hline $\mathrm{Na}_{2} \mathrm{O}$ & 3.58 & 3.46 \\
\hline $\mathrm{K}_{2} \mathrm{O}$ & 3.66 & 3.71 \\
\hline $\mathrm{P}_{2} \mathrm{O}_{5}$ & 0.21 & 0.23 \\
\hline LOI & 1.44 & 1.68 \\
\hline Total & 98.04 & 98.26 \\
\hline $\mathrm{A} / \mathrm{NK}$ & 1.5 & 1.6 \\
\hline $\mathrm{A} / \mathrm{CNK}$ & 1.2 & 1.2 \\
\hline Co & 82 & 70 \\
\hline V & 45 & 52 \\
\hline $\mathrm{Pb}$ & 20 & 20 \\
\hline $\mathrm{Zn}$ & 77 & 76 \\
\hline Sn & 4 & 3 \\
\hline $\mathrm{Cr}$ & 30 & 30 \\
\hline $\mathrm{Cu}$ & 17 & 15 \\
\hline $\mathrm{Ni}$ & 6 & 9 \\
\hline $\mathrm{Rb}$ & 152.0 & 153.5 \\
\hline Cs & 8.2 & 6.3 \\
\hline $\mathrm{Ba}$ & 693 & 933 \\
\hline $\mathrm{Sr}$ & 145 & 185 \\
\hline $\mathrm{Tl}$ & 0.6 & 0.6 \\
\hline $\mathrm{Ga}$ & 20 & 20 \\
\hline Та & 0.9 & 0.9 \\
\hline $\mathrm{Nb}$ & 10.7 & 11.6 \\
\hline Hf & 6.1 & 7.6 \\
\hline $\mathrm{Zr}$ & 214 & 273 \\
\hline Y & 33.6 & 30.6 \\
\hline Th & 9 & 10 \\
\hline U & 3.2 & 3.2 \\
\hline $\mathrm{La}$ & 30.0 & 34.2 \\
\hline $\mathrm{Ce}$ & 59.6 & 69.6 \\
\hline $\operatorname{Pr}$ & 7.45 & 8.50 \\
\hline Nd & 29 & 33 \\
\hline Sm & 6.3 & 6.7 \\
\hline $\mathrm{Eu}$ & 1.1 & 1.3 \\
\hline Gd & 6.6 & 7.0 \\
\hline $\mathrm{Tb}$ & 1.0 & 1.0 \\
\hline Dy & 6.4 & 6.2 \\
\hline Но & 1.3 & 1.2 \\
\hline Er & 3.8 & 3.4 \\
\hline $\mathrm{Tm}$ & 0.54 & 0.50 \\
\hline $\mathrm{Yb}$ & 3.5 & 3.3 \\
\hline $\mathrm{Lu}$ & 0.50 & 0.47 \\
\hline$\Sigma$ REE & 157.1 & 176.4 \\
\hline $\mathrm{La}_{\mathrm{N}} / \mathrm{Yb}_{\mathrm{N}}$ & 5.64 & 6.95 \\
\hline $\mathrm{Eu} / \mathrm{Eu}^{*}$ & 0.53 & 0.59 \\
\hline
\end{tabular}

A/CNK A $=$ mol. $\% \mathrm{Al}_{2} \mathrm{O}_{3}, \mathrm{C}=$ mol. $\% \mathrm{CaO}, \mathrm{N}=$ mol. $\% \mathrm{Na}_{2} \mathrm{O}, \mathrm{K}=$ mol. \% $\mathrm{K}_{2} \mathrm{O}, \mathrm{CNK}=\mathrm{C}+\mathrm{N}+\mathrm{K}, \mathrm{NK}=\mathrm{N}+\mathrm{K}$
Using the $\mathrm{K}_{2} \mathrm{O}$ vs. $\mathrm{SiO}_{2}$ systematics of Peccerillo and Taylor (1976), the Zawidów granodiorite is classified as high-K calc-alkaline, with transitions to both normal calcalkaline and shoshonitic suites (Białek 2007).

\subsection{Trace elements}

Two new analyses of undeformed Zawidów granodiorites (Tab. 1), together with ten archive analyses of these rocks (Białek 1999b), eight earlier reported analyses of the Izera and Kowary granites (Oberc-Dziedzic et al. 2005, 2010) and two analyses of the Lusatian greywackes (WL and ZGORZ; Oberc-Dziedzic et al. 2009) have been compared in multielement diagrams normalized to chondrite (Sun and McDonough 1989) (Fig. 2).

Multielement diagrams for all the rocks show a strong enrichment of the most incompatible elements (Cs, Rb, $\mathrm{Ba}, \mathrm{K}, \mathrm{Th}, \mathrm{U}$, LREE), with distinct positive $\mathrm{Pb}$ anomalies and strongly negative anomalies for $\mathrm{Nb}, \mathrm{Sr}, \mathrm{P}, \mathrm{Eu}$ and

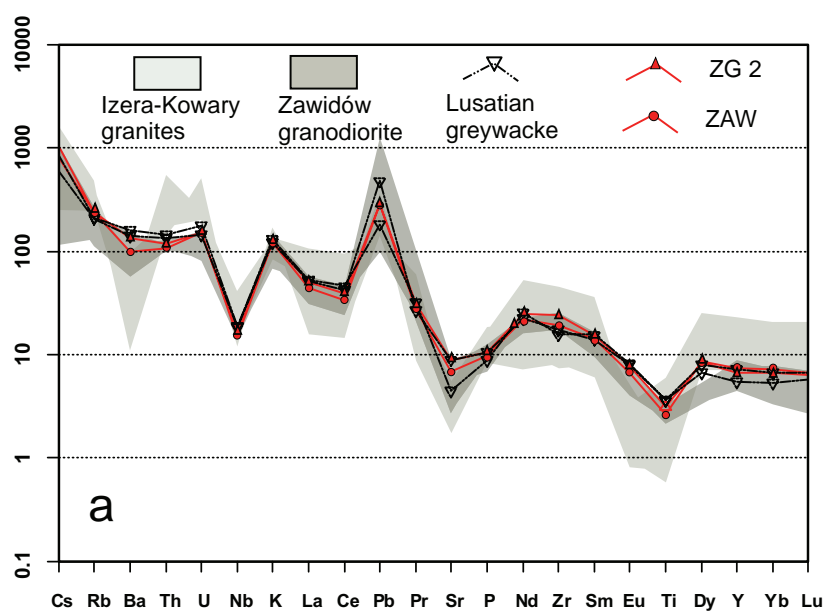

$\stackrel{0}{\circ}$

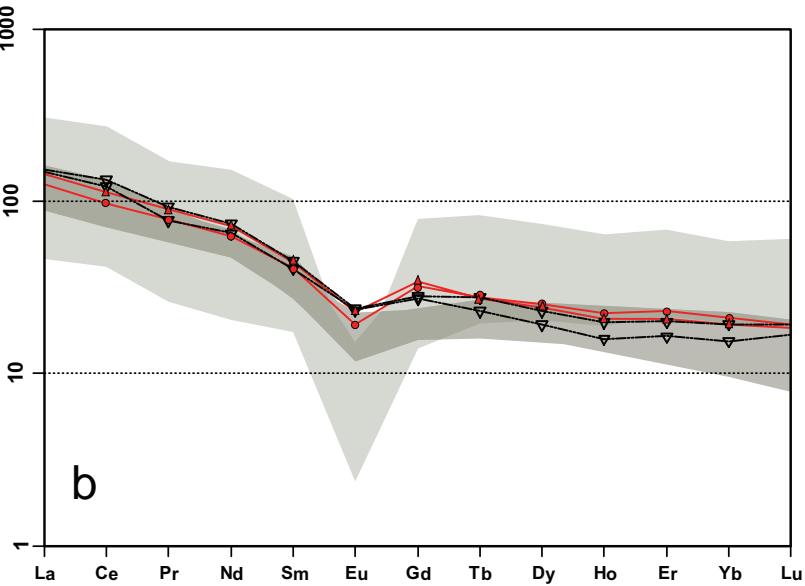

Fig. 2 Chondrite-normalized multi-element diagram (a) and Chondritenormalized rare earth element (REE) plot (b), using normalization values of Sun and McDonough (1989). Samples of the Zawidów granodiorite (Tab. 1) and Lusatian greywacke (Oberc-Dziedzic et al. 2009), are compared with data for undeformed Izera-Kowary granites (ObercDziedzic et al. 2005, 2009) and Zawidów granodiorite (Białek 1999b). 
Ti (Fig. 2a). The magnitude of $\mathrm{Nb}, \mathrm{Sr}$ and $\mathrm{Ti}$ anomalies is almost identical for the Lusatian greywacke and the Zawidów granodiorite, and higher for the Izera-Kowary granites. Barium contents decrease from the Lusatian greywacke, in which it is more than $100 \times$ higher than in chondrite, to the Izera-Kowary granites.

In the Zawidów granodiorite, the total REE contents (157-177 ppm; Tab. 1; Fig. 2b) are similar as in the Lusatian greywacke (173-191 ppm; Oberc-Dziedzic et al. 2009). The contents of REE in the Izera and Kowary granites vary from 18 to 409 ppm (Oberc-Dziedzic et al. 2005, 2010). The chondrite-normalized REE patterns show that, despite the different concentrations of REE in particular rock varieties, the proportions between them are similar. The $\mathrm{La}_{\mathrm{N}} / \mathrm{Yb}_{\mathrm{N}}$ ratios in the Zawidów granodiorite (5.64-6.95, Tab. 1) are lower than in the Lusatian greywacke (7.36-8.93; Oberc-Dziedzic et al. 2009), but higher than in the Izera granites (3.64-5.51; Oberc-Dziedzic et al. 2005).

The negative anomaly in the Lusatian greywacke (Eu/ $\mathrm{Eu}^{*}=0.67-0.70$; Oberc-Dziedzic et al. 2010) and in the Zawidów granodiorite (0.53-0.59; Tab. 1) are not as deep as those in the Izera-Kowary granites (0.11-0.42; ObercDziedzic et al. 2005, 2010).

\subsection{Sm-Nd isotope systematics}

In the Lusatian greywacke, ${ }^{147} \mathrm{Sm} /{ }^{144} \mathrm{Nd}$ ratios are 0.1149 and 0.1173 , but significantly higher in the Zawidów granodiorite, 0.1234 and 0.1244 (Tab. 2). In the Izera granites, this ratio shows a large scatter, between 0.1332 and 0.2219 (Oberc-Dziedzic et al. 2005, 2010).

The Lusatian greywacke has $\varepsilon \mathrm{Nd}_{570}$ values of -7.4 and -7.5 (Tab. 2). The Zawidów granodiorites show a more radiogenic $\mathrm{Nd}$ isotope signature, with $\varepsilon \mathrm{Nd}_{540}$ values of -4.6 and -4.7 (Tab. 2). The epsilon Nd values calculated for the possible younger age of 510 Ma would be only by c. 0.3 epsilon-units lower $(-5.0$ to -4.9$)$. The IzeraKowary granites show intermediate $\varepsilon \mathrm{Nd}_{500}$ values, from -5.2 to -6.9 (Oberc-Dziedzic et al. 2005, 2010).

Single-stage model ages (DePaolo, 1981a), $\mathrm{T}_{\mathrm{DM}}$, are 1.68 and $1.70 \mathrm{Ga}$ for the Lusatian greywacke and 1.52 and $1.54 \mathrm{Ga}$ for the Zawidów granodiorite (Tab. 2). The $\mathrm{T}_{\mathrm{DM}}$ for the Izera granites are somewhat higher, 1.73 to $2.17 \mathrm{Ga}$, with a mean of $1.89 \mathrm{Ga}$ (Oberc-Dziedzic et al. 2005).

\section{SHRIMP zircon study}

\subsection{Methods}

The selected sample, $c .5 \mathrm{~kg}$ in weight, was crushed and the heavy mineral fraction $(0.06-0.25 \mathrm{~mm})$ separated using a standard procedure with heavy liquid (tetrabromoethane, $\mathrm{C}_{2} \mathrm{H}_{2} \mathrm{Br}_{4}$ ) and magnetic separation. Zircons were handpicked under a microscope, mounted in epoxy and polished. Transmitted and reflected light photomicrographs were made along with CL images in order to select grains and choose sites for analysis (Fig. 3). The Sensitive High Resolution Ion Microprobe (SHRIMP II) at the Centre of Isotopic Research (CIR) at the AllRussian Geological Research Institute (VSEGEI) in St. Petersburg was used to determine zircon ages in the samples selected. In-situ U-Pb analyses were performed in the peak-jumping mode by using a secondary electron multiplier, following the procedure described in Williams (1998) and Larionov et al. (2004). A primary beam of molecular oxygen was employed to bombard zircon in order to sputter secondary ions. The elliptical analytical spots had a size of c. $27 \times 20 \mu \mathrm{m}$, and the corresponding ion current was $c$. $4 \mathrm{nA}$. The sputtered secondary ions were extracted at $10 \mathrm{kV}$. The $80 \mu \mathrm{m}$ wide slit of the secondary ion source, in combination with a $100 \mu \mathrm{m}$ multiplier slit, allowed mass-resolution of $\mathrm{M} / \Delta \mathrm{M} \geq 5000$ ( $1 \%$ valley) so that all the possible isobaric interferences were resolved. One-minute rastering over a rectangular area of c. $60 \times 50 \mu \mathrm{m}$ was employed before each analysis in order to remove the gold coating and any surface contamination by common lead.

The following ion species were measured in sequence: ${ }^{196}\left(\mathrm{Zr}_{2} \mathrm{O}\right){ }^{204} \mathrm{~Pb}-$ background (c. $\left.204 \mathrm{AMU}\right){ }^{206} \mathrm{~Pb}-{ }^{207} \mathrm{~Pb}-$ ${ }^{208} \mathrm{~Pb}-{ }^{238} \mathrm{U}-248 \mathrm{ThO}-{ }^{254} \mathrm{UO}$ with integration time ranging from 2 to 20 seconds. Four cycles for each spot analyzed were acquired. Each fifth measurement was carried out on the zircon $\mathrm{Pb} / \mathrm{U}$ standard TEMORA 1 (Black et al. 2003) with an accepted ${ }^{206} \mathrm{~Pb} / 238 \mathrm{U}$ age of $416.75 \pm 0.24 \mathrm{Ma}$. The 91500 zircon with a U concentration of $81.2 \mathrm{ppm}$ and a ${ }^{206} \mathrm{~Pb} /{ }^{238} \mathrm{U}$ age of $1062.4 \pm 0.4 \mathrm{Ma}$ (Wiedenbeck et al. 1995) was applied as a U-concentration standard. Error in TEMORA standard calibration was $0.78 \%(1 \sigma)$.

The results were processed with the SQUID v1.12 (Ludwig 2005a) and ISOPLOT/Ex 3.22 (Ludwig 2005b) software, using the decay constants of Steiger and Jäger

Tab. 2 Sm-Nd isotope data for the Zawidów granodiorite and Lusatian greywacke

\begin{tabular}{|c|c|c|c|c|c|c|c|c|c|c|}
\hline & Rock & Sample & Sm (ppm) & Nd (ppm) & ${ }^{147} \mathrm{Sm} /{ }^{144} \mathrm{Nd}$ & ${ }^{143} \mathrm{Nd} /{ }^{144} \mathrm{Nd}$ & $\varepsilon \mathrm{Nd}_{0}$ & $\varepsilon \mathrm{Nd}_{570 \text { Ma }}$ & $\varepsilon \mathrm{Nd}_{540 \mathrm{Ma}}$ & $\mathrm{T}_{\mathrm{DM}}(\mathrm{Ga})$ \\
\hline 1 & Lusatian & ZGORZ & 7.11 & 36.6 & 0.1173 & 0.511967 (3) & -13.1 & -7.4 & & 1.70 \\
\hline 2 & greywacke & WL & 6.31 & 33.2 & 0.1149 & $0.511953(4)$ & -13.4 & -7.5 & & 1.68 \\
\hline 3 & Zawidów & ZAW & 6.57 & 31.9 & 0.1244 & $0.512144(5)$ & -9.7 & & -4.7 & 1.54 \\
\hline 4 & granodiorite & ZG 2 & 6.78 & 33.3 & 0.1231 & $0.512142(5)$ & -9.7 & & -4.6 & 1.52 \\
\hline
\end{tabular}




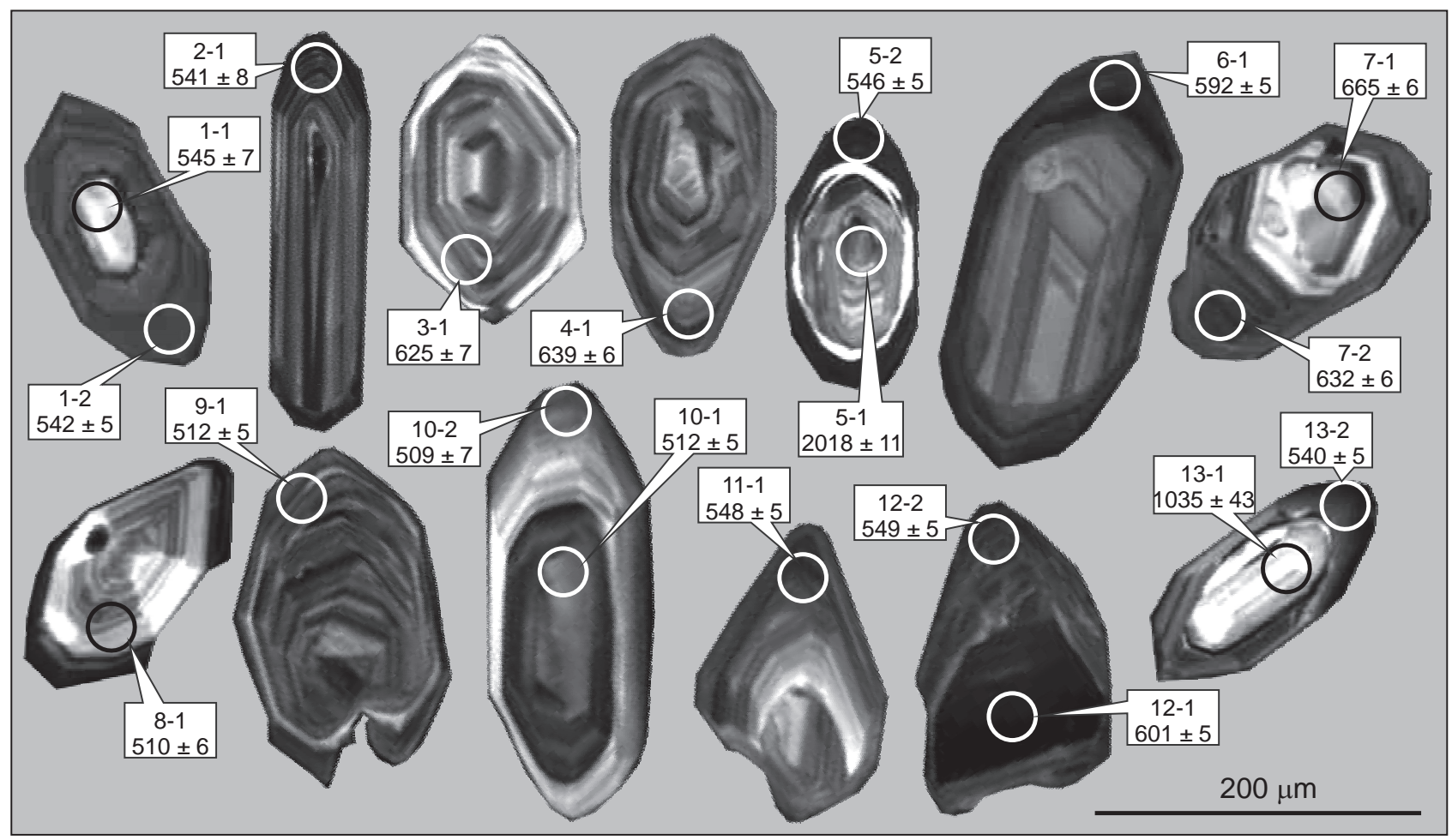

Fig. 3 Cathodoluminescence images of zircons analyzed from granodiorite ZG 2. Analytical spots correspond to those in Tab. 3 ; ${ }^{206} \mathrm{~Pb} /{ }^{238} \mathrm{U}$ ages and $1 \sigma$ errors are given.

(1977). The common lead correction was done using measured ${ }^{204} \mathrm{~Pb}$ and the isotope composition given for the appropriate age by the two-stage $\mathrm{Pb}$ evolutionary model of Stacey and Kramers (1975). The ages given in text, if not additionally specified, are ${ }^{207} \mathrm{~Pb} /{ }^{206} \mathrm{~Pb}$ ages for zircons older than $700 \mathrm{Ma}$, and ${ }^{206} \mathrm{~Pb} / 238 \mathrm{U}$ ages for those younger than $700 \mathrm{Ma}$. The errors are quoted at $1 \sigma$ level for individual points, and at $2 \sigma$ level in the Concordia diagram, for Concordia ages or any previously published ages discussed in the text.

\subsection{Sample characteristics}

Sample of the Zawidów granodiorite ZG 2, used for the SHRIMP study, was collected from an exposure located in the town park in Zgorzelec, on the eastern bank of the Nysa Łużycka River. This granodiorite is a medium- to coarse-grained rock, with a week preferred orientation of feldspars. Euhedral plagioclase laths, 4 to $8 \mathrm{~mm}$ in length, are frequently zoned, with zonation highlighted by breakdown products (mainly sericite). Rims of plagioclase are clear and uneven. Small plagioclase grains forming inclusions in K-feldspars, and part of the grains in the groundmass, show tiling. K-feldspar is anhedral, without cross-hatched twining. In places, it reveals patchy perthites. Quartz is anhedral, with undulose extinction. Biotite forms coarse flakes with undulose extinction and strong pleochroism: $\alpha$-yellow, $\gamma$-red-brown. It en- closes zircon with wide pleochroic haloes, and elliptical inclusions of apatite.

\subsection{Zircon characteristics}

The zircon population in the granodiorite is rather homogeneous: the euhedral crystals are short- to longprismatic, clear and transparent, with a few inclusions. Characteristically, they comprise two pyramids, with the steep (211) dominating over the shallow one (101), resulting in barrel-shaped crystals.

The cathodoluminescence (CL) images reveal various internal structures (Fig. 3). Most of the zircons show oscillatory, "igneous-style" zoning. Many of them, especially those short-prismatic, contain distinct cores, usually CL-brighter than the regularly zoned magmatic overgrowth. Internal parts of some crystals are CL-dark, and a few grains have very bright, thin external rims. However, some grains (e.g. 5.2, 8.1) have dark rims suggesting their possible late-magmatic or metamorphic origin.

\subsection{SHRIMP ages}

All 19 analytical points in 13 crystals yielded concordant or slightly discordant ages, with degree of discordance, $D$, ranging between -8 and $+5 \%$ (Tab. 3). The common lead contents, ${ }^{206} \mathrm{~Pb}$, are low, usually accounting for less 


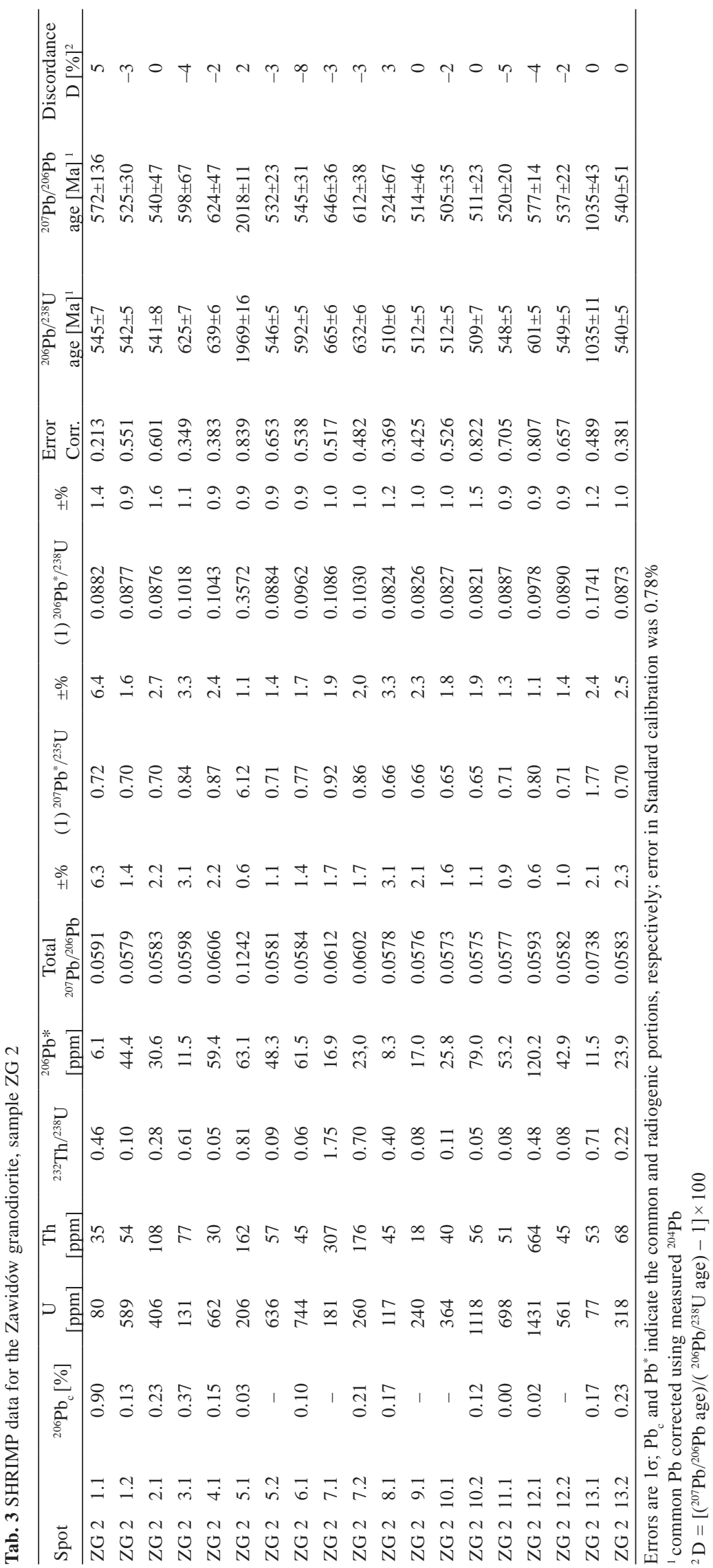

than $0.3 \%$ of the measured ${ }^{206} \mathrm{~Pb}$. The $\mathrm{U}$ and Th concentrations are highly variable (77-1431 and 18-664 ppm, respectively). The ${ }^{232} \mathrm{Th} /{ }^{238} \mathrm{U}$ ratios are low to moderate, mostly between 0.05 and 0.81 (Tab. 3), typical of zircons that crystallize within igneous, late-magmatic- to metamorphic conditions (we should notice, however, that there is no evidence of metamorphism in the studied granodiorite).

The oldest Precambrian dates $\left({ }^{207} \mathrm{~Pb} /{ }^{206} \mathrm{~Pb}\right.$ ages) have been obtained from two points located in crystal cores (Fig. 3): $2018 \pm 11$ Ma (5.1) and $1035 \pm 43 \mathrm{Ma}$ (13.1). Six other points yielded Neoproterozoic ${ }^{206} \mathrm{~Pb} /{ }^{238} \mathrm{U}$ ages, scattered between $592 \pm 5$ (point 6.1) and $665 \pm 6$ Ma (point 7.1), with discordance $D$ of 0 to $-8 \%$ (Tab. 3).

The remaining majority of zircon analyses fall within two distinct groups of the following Concordia ages: $544 \pm 4$ Ma (7 points) and $511 \pm 5$ Ma (4 points; Fig. 4b). Both groups are formed by analyses from core as well as rim domains. In the older group, two points (1.1 and 5.2; Fig. 3) are represented by CL-bright distinct cores, four others by rather dark rims (points 2.1, 11.1, 12.2 and 13.2). Four analytical points in three grains of the younger group gave the following ages: point 8.1 (core of magmatically-zoned crystal) $-510 \pm 6 \mathrm{Ma}$, point 9.1 (rim) $512 \pm 5 \mathrm{Ma}$, point 10.1 (CL-dark core, with $\sim 360$ ppm U) $-512 \pm 5 \mathrm{Ma}$ and point 10.2 (CL-brighter rim of the same crystal, with $\sim 1120$ ppm U) $-509 \pm 7$ Ma.

\section{Discussion}

\subsection{Source and petrogenesis}

The strong $\mathrm{Nb}, \mathrm{Ti}$ and $\mathrm{Sr}$ anomalies shown by the chondrite-normalized trace element diagrams for the Lusatian greywacke, the Lusatian granodiorite and the Izera granites are typical of materials from the upper continental crust (Taylor and McLennan 1985; McLennan et al. 2006). The depth of the $\mathrm{Nb}$ anomaly is practically the same in all the rocks studied (Fig. 2a). This may indicate that the granodiorites and granites could have inherited their chemical and isotopic features from a sedimentary source 

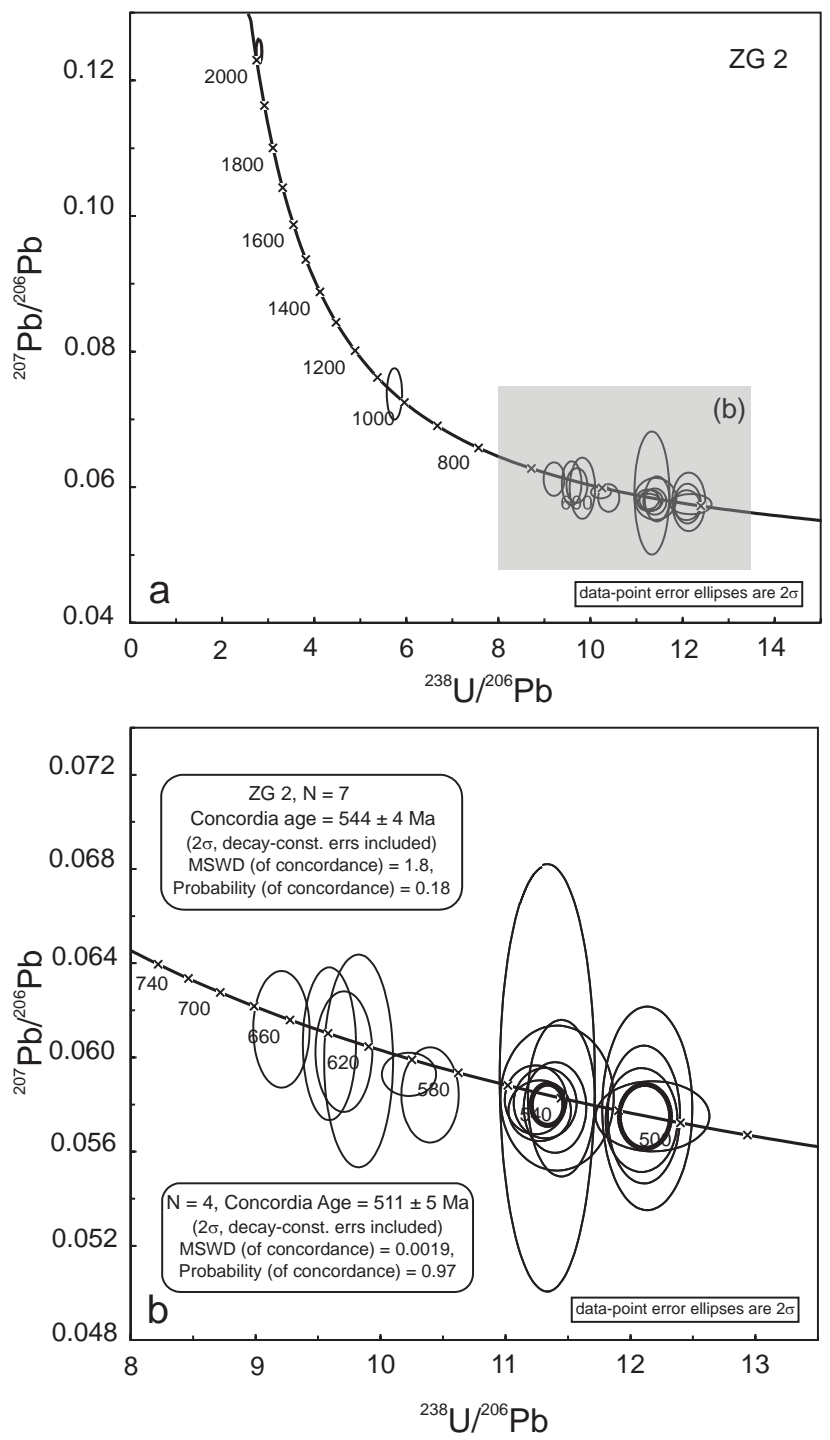

Fig. 4 Concordia diagram showing results of all SHRIMP zircon analyses from granodiorite ZG 2 (a). b - Zoomed up portion of the same diagram showing Concordia ages of about 544 Ma for seven selected zircon grains and of about 511 Ma for four selected domains.

material, possibly similar to the Lusatian greywacke. However, the negative $\mathrm{Ti}$ anomaly, which is similar in the greywacke and the Zawidów granodiorite, but much deeper in the Izera granites (Fig. 2a), suggests that the magma of the Izera granites separated either from a Ti-poor source or from a residuum containing a Ti-rich phase, e.g. rutile. Furthermore, the deeper negative anomaly of $\mathrm{Eu} / \mathrm{Eu}^{*}$ in the Izera granites may reflect a more advanced plagioclase fractionation during differentiation of the Izera granite magmas, and/or a source more depleted in Eu.

The ${ }^{147} \mathrm{Sm} /{ }^{144} \mathrm{Nd}$ ratios in the Zawidów granodiorite (0.1234 and 0.1244, Tab. 2) are lower than in the Izera granites (0.1332-0.2219, Oberc-Dziedzic et al. 2005, 2010). The great scatter of the ${ }^{147} \mathrm{Sm} /{ }^{144} \mathrm{Nd}$ ratios in the
Izera granites most likely reflects the fractionation of a LREE-rich mineral (e.g. monazite), leading to progressive rise of $\mathrm{Sm} / \mathrm{Nd}$ ratio in the residual melt.

The Lusatian greywackes show $\varepsilon \mathrm{Nd}_{570}$ values of -7.5 , lower than those in the Zawidów granodiorite and the Izera granite. These values indicate that the sedimentary basin was fed by clastic components derived from average source regions with low time-integrated Sm/Nd ratios, as typical of the upper continental crust. There is no evidence for any significant contribution from igneous rocks containing a substantial proportion of juvenile (mantle-derived) materials, as would be typical of subduction-related magmas, or for the mafic end-member of a bimodal igneous suite emplaced in a rift setting.

Although also clearly derived from magmas that were enriched in LREE on a secular basis, the Zawidów granodiorites have a distinctly more radiogenic $\mathrm{Nd}$ isotope signature, as shown by their $\varepsilon \mathrm{Nd}_{540}$ values of $\sim$ -4.6 . This observation precludes materials similar to the Lusatian greywackes as the sole source for the granodiorites, and requires the contribution of component(s) with more radiogenic $\mathrm{Nd}$ isotopes, either from a lower crustal source, or as a more juvenile contribution at the time of magma genesis. Compared to the Zawidów granodiorite, the lower $\varepsilon \mathrm{Nd}$ values ( -5.2 to -6.9 , Oberc-Dziedzic et al. $2005,2010)$ for the Izera granites reflect a higher contribution of mature crustal components in these chemically more evolved rock-types.

On general grounds, $\mathrm{Nd}$ model ages do not have any geological significance. This is simply because they are based on simplistic evolutionary models, a condition which is clearly violated in cases of mixing processes, which are very common in sedimentary and in igneous contexts. However, $\mathrm{Nd}$ model ages convey a geochemical information, specifically the average crustal residence age, based on the observation that the major fractionation of Sm from Nd occurs during extraction of low-degree partial melts from the mantle. Concerning sedimentary clastic rocks, or granitoid magmas derived therefrom, $\mathrm{Nd}$ model ages are interpreted to reflect the broad, averaged crustal residence age of the different components which contributed to their formation. Because most crustal rocks contain LREE in non-negligible amounts, Nd model ages are not prone to strong biasing effects, in contrast with zircon age spectra which, by essence, cannot record the contribution of zircon-poor sources adequately. These model ages reflect the weighted average of the different components involved in the sedimentary mixing.

In the pre-Variscan realm, a large body of data shows that the mixing was dominated by two components, $c .2 .0$ $\mathrm{Ga}$ and $c$. 0.6 Ga old, corresponding to the major rockforming episodes known from the West African Craton and its Pan-African margins (e.g. Linnemann et al. 2004). The Nd model ages for the Lusatian greywacke $\left(\mathrm{T}_{\mathrm{DM}}=\right.$ 
1.68 and $1.70 \mathrm{Ga}$ ) and the Zawidów granodiorite (1.52 and $1.54 \mathrm{Ga}$ ) are much older than either the deposition or igneous emplacement ages (Tab. 2), and emphasize the dominant role of recycled, old crustal components, albeit to a somewhat lesser degree in the granodiorites. They fit well the apparent average crustal residence ages, from 1.4 to $1.7 \mathrm{Ga}$, assigned by Liew and Hofmann (1988) to metamorphic, sedimentary and granitic rocks involved in the Hercynian Fold Belt of Central Europe. The $T_{D M}$ model ages for the Izera granites are somewhat higher, 1.73 to $2.17 \mathrm{Ga}$, with a mean of $1.89 \mathrm{Ga}$, but these might have been biased to spuriously old values by late-stage fractionation of $\mathrm{Sm} / \mathrm{Nd}$ ratios associated with the removal of LREE-rich accessories in these more evolved magmas (Oberc-Dziedzic et al. 2005).

The age spectra of the inherited zircons: $c$. $2.0 \mathrm{Ga}, 1.0$ Ga and 592-665 Ma from the Zawidów granodiorite (this work), and c. 3.4 Ga, 1.8 Ga and 609-556 Ma from the Izera granites (Oberc-Dziedzic et al. 2009) are broadly similar to the ages reported for detrital zircons from the Lusatian greywacke: $c$. 2.4 to $1.9 \mathrm{Ga}$ and $~ 730-540 \mathrm{Ma}$ (Linnemann et al. 2004). Similar zircon age spectra were found in the Złotniki Lubańskie schists: c. 2.1-1.9 Ga, and c. 620 and $559 \mathrm{Ma}$ (Żelaźniewicz et al. 2009).The only exception represents the newly obtained age of $c .1 .0 \mathrm{Ga}$, which has not been reported from Lusatia yet, but sporadically found throughout Saxo-Thuringia (Zeh et al. 2001).

The age spectra of inherited zircons suggest that the likely protolith for both the early Cambrian Lusatian granodiorite and the late Cambrian/early Ordovician Izera granites, could have been similar to the source rocks that delivered detrital material to the upper Neoproterozoic Lusatian greywacke. However, this is not well supported by $\mathrm{Nd}$ isotopes. In contrast, they indicate that the possible metasedimentary protolith of the Lusatian granodiorite contained a greater proportion of isotopically more juvenile components. This could have been in the form of mafic/intermediate volcaniclastic rocks in their mixed, metasedimentary lower crustal source. Alternatively, mantle-derived magmas might have provided a volumetrically minor, but a thermally important contribution at the time of generation of the granodioritic magma.

\subsection{Significance of Cambro-Ordovician ages}

In the granodiorite ( $Z G$ 2), the majority of zircon analyses yielded a Concordia age of $544 \pm 4$ Ma. Four analytical points, located both in cores and rims, gave a Concordia age of $511 \pm 5 \mathrm{Ma}$. Zircons of similar ages were ascertained (using the same SHRIMP method and similar sampling and analytical procedures) in the Izera granites and orthogneisses:

- fine-grained granite (loc. Chmieleń, sample $\mathrm{CH}$ ) -

9 analytical points in cores and rims in prismatic crystals of various internal structures form a group of scattered ages of 538-509 Ma (Oberc-Dziedzic et al. 2009);

- coarse-grained granite (loc. Wrzeszczyn, sample WR1) - 4 analytical points, mostly in CL-dark zoned rims (late-magmatic zircons), with ages between 517 and 510 Ma (Oberc-Dziedzic et al. 2009);

- fine-grained gneiss (loc. Izerski Stóg, sample Istog) - 5 analytical points, mostly in mantles of zoned prismatic crystals, ranging between 536 and $512 \mathrm{Ma}$ (Żelaźniewicz et al. 2009);

- leucogranite (loc. Kotlina, sample Kotli) - 5 analytical points in mantles and rims of zoned prismatic crystals, yielding ages between 539-510 Ma (Żelaźniewicz et al. 2009).

In all these samples, a proportion of dates "transitional" between zircon ages regarded as the likely maximum age of the Zawidów granodiorite intrusion (c. 540-545 $\mathrm{Ma}$ ), and as the Izera granite emplacement (c. 500-510 Ma), is about $25 \%$.

Analytical limitations (such as poor counting statistics on ${ }^{207} \mathrm{~Pb} /{ }^{206} \mathrm{~Pb}$ and ${ }^{207} \mathrm{~Pb} /{ }^{235} \mathrm{U}$ ratios in the SIMS method used, implying that ${ }^{206} \mathrm{~Pb} /{ }^{238} \mathrm{U}$ ages are, strictly speaking, apparent ages) put significant constraints on the attempts of geological interpretation of the SHRIMP dates obtained in this work, with two a priori possible alternatives:

1. The quoted ${ }^{206} \mathrm{~Pb} /{ }^{238} \mathrm{U}$ ages are truly concordant and thus provide unbiased, accurate estimates for the zircon growth ages. If so, the $c$. 540 Ma zircons originated during the crystallization of older granitoid magma, while the 510 Ma ones grew during a subsequent thermal event (broadly contemporaneous with the emplacement of the Izera-type granitoids). The 540 Ma grains could be antecrysts, inherited from the source (which would be very young in this case), or xenocrysts, incorporated from the country rocks during ascent and emplacement of the younger magma at c. $510 \mathrm{Ma}$. Both zircon age groups would reflect igneous episodes within a protracted magmatic activity, lasting at least $c$. $30 \mathrm{My}$.

2. The ${ }^{206} \mathrm{~Pb} /{ }^{238} \mathrm{U}$ ages obtained for either the $\sim 540$ or the $\sim 510$ Ma groups, or both, are merely apparent ages, due to real discordance of the data points beyond the resolving power of SHRIMP dating. In this more conservative interpretation of the data, several models are permitted, specifically (but not exhaustively):

A - The $c$. 540 Ma grains provide a close, though minimum estimate of the true igneous emplacement age, and the $c .510 \mathrm{Ma}$ ages reflect a much younger radiogenic lead loss. It could have been due to the Variscan tectono-metamorphic overprint, which affected the eastern part of the Lusatian Massif, together with in Karkonosze-Izera Massif (Żelaźniewicz et al. 2003, 2004). 
B - Alternatively, subtle unresolved inheritance might have jeopardized the interpretation of the data. In this case, the $510 \mathrm{Ma}$ age might provide an upper estimate for the true age of igneous emplacement, while the c. $540 \mathrm{Ma}{ }^{206} \mathrm{~Pb} /{ }^{238} \mathrm{U}$ ages would be apparent, reflecting inheritance of significantly older zircons.

Keeping in mind the above-mentioned methodological limitations and consequent interpretation ambiguities, the zircon ages older than $c .510$ Ma can be interpreted as representing inherited material or as an artefact resulting from analytical overlapping of the older core and younger rim ages (Oberc-Dziedzic et al. 2009). However, it can not be excluded that such a wide span of "magmatic" ages both in the Zawidów granodiorite and the Izera granites may indicate prolonged or multiphase magmatic activity. Thus, the crystallization of the Zawidów granodiorite could have taken place 30 My later than assumed based on the earlier datings, whereas the Izera granites could begin their magmatic evolution several My earlier than previously assumed. This model, however, would have to be verified keeping in mind, e.g., that we are dealing with relatively shallow plutons which should have cooled down rather quickly. They may reflect two discrete igneous episodes, separated by c. $30 \mathrm{My}$, and possibly involving reworking of successive magma intrusions.

Within a wider plate-tectonic context, the magmatic pulses would be related to inferred different tectonic regimes: (a) slab break-off of the subducted oceanic plate (Linnemann et al. 2007) ending the Cadomian cycle, clearly represented by the Lusatian granodiorite and also by the inherited materials (c. 540 Ma old) in the Zawidów granodiorite, and (b) the Cambro-Ordovician rifting generating the Izera/Rumburk granites (Pin et al. 2007). This hypothesis, however, is proposed so far only for the Zawidów granodiorite, in the eastern periphery of the Lusatian Massif, close to the Izera granites of the Izera-Karkonosze Massif. Whether the model of successive events of granitic magmatism is valid for the granodiorites in the western part of the Lusatian Massif would need further testing by more geochronological work.

Summing up the geochronological data, our reconnaissance SHRIMP zircon study of the Zawidów granodiorite yielded two main age populations, at c. 540 and $510 \mathrm{Ma}$, which are difficult to interpretat unequivocally. At this stage, however, we prefer a scenario assuming that both zircon age groups in the granodiorite reflect important igneous episodes, in the framework of a protracted magmatic evolution, involving reworking of successive magma intrusions (model 1), during tectonic regime changing from the ceasing Cadomian cycle to the Cambro-Ordovician initial rifting. However, based of the available data, we cannot exclude other possible interpretations. To make a substantiated choice between possible scenarios, we would need more high-precision dates.

\section{Conclusions}

1. The Zawidów (Lusatian) granodiorite and the Izera granites differ in geochemical parameters that indicate lower fractionation of granodioritic magmas than granitic ones.

2. The slightly more radiogenic Nd isotopes of the Zawidów granodiorite imply a greater participation of more juvenile materials, possibly mafic/intermediate volcaniclastic in the predominantly mature crustal sources or, alternatively, a small contribution of mantle-derived melts at the time of granodioritic magma generation.

3. The zircons from granodiorite ZG 2 are mostly homogeneous and were probably produced in magmatic events. However, rather abundant and diverse zircon inheritance of $c$. 2.0, 1.0 Ga and between 597 and 665 Ma suggests that metasedimentary rocks (broadly similar to the Lusatian greywacke) were likely the main magma source.

4. Two well-defined main ${ }^{206} \mathrm{~Pb} /{ }^{238} \mathrm{U}$ age groups, at $c$. 540 and $510 \mathrm{Ma}$, could be tentatively interpreted as the main zircon-producing magmatic events during Early and Late Cambrian times, respectively. Their presence in one sample of the granodiorite indicates that the rock could be a product of magmatic reworking (at $\sim 510 \mathrm{Ma}$ ) of an earlier granitoid ( 540 Ma), but the age of $\sim 510$ Ma might also be interpreted as the granodiorite emplacement age.

5. The existence of zircons dated at c. 540 and $510 \mathrm{Ma}$ in the Zawidów granodiorite and at $c$. 538-509 Ma in the Izera granites may suggest a prolonged granitoid magmatic activity that involved two discrete magmatic pulses separated by $c$. 30 My time gap between the Early and Late Cambrian times.

6. Provided that the ${ }^{206} \mathrm{~Pb} /{ }^{238} \mathrm{U}$ ages can be considered as significant (that is, correspond to really concordant spot analyses), the granitoid magmatic pulses, between c. 540 and $510 \mathrm{Ma}$, might reflect tectonothermal crustal processes marking the change of the global-tectonic environment, from the final Cadomian convergence, to the initiation of the Late Cambro-Ordovician rifting along the Gondwana margin, eventually leading to the opening of the Palaeozoic Rheic Ocean.

Acknowledgements. The research was carried out under the Project N307 008 32/0314 of the Polish Ministry of Science and Higher Education. Additional support came from internal grants 1017/S/ING and 2022/W/ING of the University of Wrocław. The zircons were separated by Kalina Dymna. The SHRIMP analyses were performed in the Centre of Isotopic Research (CIR) at the All-Russian Geological Research Institute (VSEGEI) in St. Petersburg. Careful reviews by Ulf Linnemann and 
Armin Zeh are much appreciated and helped to improve the manuscript.

\section{References}

BERG G (1935) Erläuterungen zur Geologische Karte von Preussen und benachbarten Deutschen Ländern, Blatt Marklissa. Lief 333. Preussischen Geologischen Landesanstalt, Berlin, pp 1-40

BiAŁEK D (1999a) Chemical changes associated with deformation of granites under greenschist facies conditions: example of the Zawidów granodiorite (SE Lusatian Granodiorite Complex, Poland). Tectonophysics 303: 251-261

Biatek D (1999b) Petrography and Geochemistry of the Zawidów granodiorite. Unpublished Ph.D. thesis, University of Wrocław, pp 1-169 (in Polish)

BiAleK D (2003) Cadomian basement of Lusatia. In: Cį̨żkowski W, Wojewoda J, Żelaźniewicz A (eds) Western Sudetes: From Vendian to Quaternary. Wind, Wrocław, pp 33-40 (in Polish with English summary)

Biatek D (2007) Zawidów granodiorite from the Lusatian Massif in SW Poland. In: KozŁowski A, WiszNiEwsKa J (eds) Granitoids in Poland. Arch Mineral Monograph 1: 89-99

Black LP, Kamo SL, Allen CM, Aleinikoff JN, Davis DW, Korsch RJ, Foudoulis C (2003) TEMORA 1: a new zircon standard for Phanerozoic U-Pb geochronology. Chem Geol 200: 155-170

BorkowSKa M (1959) On the granitoids of Kudowa as compared with the main types of the acid intrusions of the Sudeten Mts. and the Sudetic Foreland. Arch Mineral 21: 229-382 (in Polish with English summary)

Chaloupský J, Červenka J, Jetel J, Králík F, Líbalová J, Píchová E, Pokorný J, Pošmourný K, Sekyra J, Shrbený O, ŠAlanskÝ K, ŠrámeK J, VÁcl J (1989) Geology of the Krkonoše and Jizerské hory Mts. Czech Geological Survey, Prague, pp 1-288 (in Czech with English summary)

De Paolo DJ (1981a) Neodymium isotopes in the Colorado Front Range and crust-mantle evolution in the Proterozoic. Nature 291: 193-196

De Paolo DJ (1981b) A Nd and Sr isotopic study of Mesozoic calc-alkaline batholiths of the Sierra Nevada and Peninsular Ranges, California. J Geophys Res 86: 10370-10488

DoмeČKa K (1970) Pre-Variscan granitoids of the West Sudeten. Sbor geol Věd, Geol 18: 161-189 (in Czech with English summary)

Dörr W, Zulauf G, Fiala J, Franke W, Vejnar Z (2002) Neoproterozoic to Early Cambrian history of an active plate margin in the Teplá-Barrandian unit - a correlation of U-Pb isotopic-dilution-TIMS ages (Bohemia, Czech Republic). Tectonophysics 352: 65-85
Gehmlich M, Linnemann U, Tichomirowa M, Lützner H, Bомвасн K (1997) Die Bestimmung des Sedimentationsalters cadomischer Krustenfragmente im Saxothuringikum durch die Einzelzirkon-Evaporatisationsmethode. Terra Nostra 5: 46-49

JANOUŠEK V, FARROW CM, ERBAN V (2006) Interpretation of whole-rock geochemical data in igneous geochemistry: introducing Geochemical Data Toolkit (GCDkit). J Petrol 47: 1255-1259

Kemnitz H (1998) Some remarks on the Neoproterozoic Lusatian greywackes, Germany, and their mafic intercalations. Acta Univ Carol, Geol 42: 443-446

Kemnitz H (2007) The Lausitz graywackes, Saxo-Thuringia, Germany - witness to the Cadomian orogeny. In: Linnemann U, Nance RD, Kraft P, Zulauf G (eds) The Evolution of the Rheic Ocean: From Avalonian-Cadomian Active Margin to Alleghenian-Variscan Collision. Geological Society of America, Special Publications 423: 97-142

Kossmat F (1927) Gliederung des varistichen Gebirgsbaues. Abh Sächs Geol Landesamts 1: 1-39

KozŁowsKa-Кoch M (1965) The granite-gneisses of Izera Highlands. Arch Mineral 25: 123-260 (in Polish with English summary)

KozŁowski K (1974) Crystalline schists and leucogranites of the Stara Kamienica-Świeradów Zdrój Belt. Geol Sudetica 9: 7-100 (in Polish with English summary)

Krauss M, Eidam J, Hammer J, Korich D (1992) Die cadomisch-variszische Entwicklung des Lausitzer Granodiorit-Komplexes. Zbl Geol Paläont I, 1/2: 71-85

Kröner A, Hegner E, Hammer J, Haase G, Bielicki KH, Krauss M, Eidam J (1994) Geochronology and Nd-Sr systematics of Lusatian granitoids, significance for the evolution of the Variscan orogen in east-central Europe. Geol Rundsch 83: 357-376

Kröner A, Jaeckel P, Hegner E, Opletal M (2001) Single zircon ages and whole rock $\mathrm{Nd}$ isotopic systematics of early Palaeozoic granitoid gneisses from the Czech and Polish Sudetes (Jizerské hory, Krkonoše Mountains and Orlice-Sněžník Complex). Int J Earth Sci (Geol Rundach) 90: 304-324

Larionov AN, Andreichev VA, Gee DG (2004) The Vendian alkaline igneous suite of northern Timan: ion microprobe $\mathrm{U}-\mathrm{Pb}$ zircon ages of gabbros and syenite. In: GeE DE, Pease VL (eds) The Neoproterozoic Timanide Orogen of Eastern Baltica. Geological Society of London Memoirs 30: 69-74

Le Fèvre B, Pin C (2005) A straightforward separation scheme for concomitant $\mathrm{Lu}-\mathrm{Hf}$ and $\mathrm{Sm}-\mathrm{Nd}$ isotope ratio and isotope dilution analysis. Anal Chim Acta 543: 209-22

Liew TC, Hofmann AW (1988) Precambrian crustal components, plutonic associations, plate environment of the Hercynian Fold Belt of Central Europe: indications 
from a Nd and Sr isotopic study. Contrib Mineral Petrol 98: 129-138

Linnemann U, Gemnlich M, Tichomirowa M, Buschmann B, Nasdala L, Jonas P, Lützner H, Bombach K (2000) From Cadomian subduction to Early Paleozoic rifting: the evolution of Saxo-Thuringia at the margin of Gondwana in the light of single zircon geochronology and basin development (Central European Variscides, Germany). In: Franke W, HaAk V, Oncken O, TANner D (eds) Orogenic Processes: Quantification and Modeling in the Variscan Belt. Geological Society London Special Publications 179: 131-153

Linnemann U, McNaughton NJ, Romer RL, Gehmlich M, Drost K, TonK T (2004) West African provenance for Saxo-Thuringia (Bohemian Massif): did Armorica ever leave pre-Pangean Gondwana? - U/Pb-SHRIMP zircon evidence and the Nd-isotopic record. Int J Earth Sci (Geol Rundsch) 93: 683-705

Linnemann U, Gerdes A, Drost K, Buschmann B (2007) The continuum between Cadomian orogenesis and opening of the Rheic Ocean: constraints from LA-ICPMS U-Pb zircon dating and analysis of plate-tectonic setting (Saxo-Thuringian zone, NE Bohemian Massif, Germany). In: Linnemann U, Nance RD, Kraft P, ZuLauf $\mathrm{G}$ (eds) The Evolution of the Rheic Ocean: From Avalonian-Cadomian Active Margin to Alleghenian-Variscan collision. Geological Society of America Special Publications 423: 61-96

LuDwIG KR (2005a). SQUID 1.12, A User's Manual. Berkeley Geochronology Center Special Publications pp 1-22

LuDWIG KR (2005b). ISOPLOT/Ex 3.22, A Geochronological Toolkit for Microsoft Excel. Berkeley Geochronology Center Special Publications pp 1-71

Marheine D, Kachlík V, Maluski H, Patočka F, ŻelaźNIEWicz A (2002) The Ar-Ar ages from the West Sudetes (NE Bohemian Massif): constraints of the Variscan polyphase tectonothermal development. In: Winchester JA, Pharaoh TC, Verniers J (eds) Paleozoic Amalgamation of Central Europe. Geological Society London Special Publications 201: 133-155

Mazur S (2003) Eastern envelope of the Karkonosze granite - cross-section of a Variscan suture zone. In: CIĘŻKOWSKI W, Wojewoda J, Żelaźniewicz A (eds) Western Sudetes: From Vendian to Quaternary. Wind, Wrocław, pp 53-66 (in Polish with English summary)

Mazur S, Aleksandrowski P (2001) The Teplá(?)/Saxothuringian suture in the Karkonosze-Izera massif, Western Sudetes, Central European Variscides. Int J Earth Sci 90: 341-360

Mazur S, KryZA R (1996) Superimposed compressional and extensional tectonics in the Karkonosze-Izera Block, NE Bohemian Massif. In: OnCKen O, JANSEN C (eds) Basement Tectonics 11, Europe and Other Regions. Kluwer, Dordrecht, pp 51-66
Mazur S, Aleksandrowski P, Kryza R, Oberc-Dziedzic T (2006) The Variscan orogen in Poland. Geol Q 50: 89-118

McLennan SM, Taylor SR, Hemming SR (2006) Composition, differentiation, and evolution of continental crust: constraints from sedimentary rocks and heat flow. In: Brown M, Rushmer T (eds) Evolution and Differentiation of the Continental Crust. Cambridge University Press, pp 92-134

MierZeJEWSKi MP (2003) The structures of the late stages of the granite magma emplacement in the Karkonosze Mts. In: CiężKowsKi W, Wojewoda J, ŻELAżNiEWicz A (eds) Western Sudetes: From Vendian to Quaternary. Wind, Wrocław, pp 81-94 (in Polish with English summary)

MierzeJEwski MP (2007) A general view on the Karkonosze granite. In: KozŁowski A, WiszniewskA, J (eds) Granitoids in Poland. Arch Mineral Monograph 1: 111-122

Oberc-Dziedzic T (1988) The development of gneisses and granites in eastern part of the Izera crystalline unit in the light of the textural investigations. Acta Uniw Wrat 997 Geol-Min 13: 1-184 (in Polish, with English summary)

Oberc-Dziedzic T (2003) The Izera granites: an attempt of the reconstruction of predeformational history. In: Ciężkowski W, Wojewoda J, Żelaźniewicz A (eds) Western Sudetes: From Vendian to Quaternary. Wind, Wrocław, pp 41-52 (in Polish with English summary)

Oberc-Dziedzic T, Pin C, Kryza R (2005) Early Palaeozoic crustal melting in an extensional setting: petrological and Sm-Nd evidence from the Izera granite-gneisses, Polish Sudetes. Int J Earth Sci 94: 354-368

Oberc-Dziedzic T, Kryza R, Pin C, Mochnacka K, LarioNov A (2009) The Orthogneiss and Schist Complex of the Karkonosze-Izera Massif (Sudetes, SW Poland): U-Pb SHRIMP zircon ages, Nd-isotope systematics and protoliths. Geol Sudetica 41: 3-24

Oberc-Dziedzic T, Kryza R, Mochnacka K, Larionov A (2010) Ordovician passive continental margin magmatism in the Central-European Variscides: U-Pb zircon data from the SE part of the Karkonosze-Izera Massif, Sudetes, SW Poland. Int J Earth Sci 99: 27-46

Opletal M, DomečKa K, VavŘín I (1983) Granitoide des Lausitzer Massivs im Südteil des Šluknov Gebiet und ihre neue petrologische Bestimmung. Sbor geol Věd, Geol 38: 141-175 (in Czech with German summary)

Peccerillo A, Taylor SR (1976) Geochemistry of Eocene calc-alkaline volcanic rocks from the Kastamonu area, northern Turkey. Contrib Mineral Petrol 58: 63-81

Pin C, Kryza R, Oberc-Dziedzic T, Mazur S, Turniak K, Waldhausrová J (2007) The diversity and geodynamic significance of Late Cambrian (c. $500 \mathrm{Ma}$ ) felsic anorogenic magmatism in the northern part of the Bohemian Massif: a review based on $\mathrm{Sm}-\mathrm{Nd}$ isotope and geochemical data. In: Linnemann U, Kraft P, NAnce D, Zulauf G (eds) The Geology of Peri-Gondwana: Ava- 
lonian-Cadomian Terranes, Adjoining Cratons, and the Rheic Ocean. Geological Society of America Special Publications 423: 209-230

Pin C, Rodriguez J (2009) Comment on "Rheic Ocean ophiolitic remnants in southern Iberia questioned by SHRIMP U-Pb zircon ages on the Beja-Acebuches amphibolites” by A. Azor et al. Tectonics 28: TC5013, doi:10.1029/2009TC002495

Pin C, Santos Zalduegui JF (1997) Sequential separation of light rare earth elements, thorium and uranium by miniaturized extraction chromatography: application to isotopic analyses of silicate rocks. Anal Chim Acta 339: 79-89

Smulikowski W (1972) Petrogenetic and structural problems of the northern cover of the Karkonosze granite. Geol Sudetica 6: 97-180 (in Polish with English summary)

StaCEY JS, KRAmers JD (1975) Approximation of terrestrial lead isotope evolution by a two-stage model. Earth Planet Sci Lett 26: 207-221

SteIger RH, JäGER E (1977) Subcommission on Geochronology: convention on the use of decay constants in geoand cosmochronology. Earth Planet Sci Lett 36: 359-362

Sun S-S, McDonough WF (1989) Chemical and isotopic systematics of oceanic basalts: implications for mantle composition and processes. In SAunders AD, Norry MJ (eds) Magmatism in the Ocean Basins. Geological Society London Special Publications 42: 313-345

Sząamacha J (1970) On the geological connections of the metamorphic rocks from the Block of Isera with those from the Block of Lusatia. Biul Inst Geol 239: 5-36 (in Polish with English summary)

TANAKA T et al. (2000) JNdi-1: a neodymium isotopic reference in consistency with LaJolla neodymium. Chem Geol 168: 279-281

TAYlor SR, Mc Lennan SM (1985) The Continental Crust: Its Composition and Evolution; An Examination of the Geochemical Record Preserved in Sedimentary Rocks. Blackwell, Oxford, pp 1-312

Tichomirowa M (2002) Zircon inheritance in diatexite granodiorites and its consequence on geochronology - a case study in Lusatia and Erzgebirge (Saxo-Thuringia, eastern Germany). Chem Geol 191: 209-224

Wiedenbeck M, Allé P, Corfu F, Griffin WL, Meier M, Oberli F, Von Quadt A, Roddick JC, Spiegel W (1995) Three natural zircon standards for U-Th-Pb, Lu-Hf, trace element and REE analyses. Geostandard Newslett 19: 1-23

Williams IS (1998) U-Th-Pb Geochronology by ion microprobe. In: McKibBen MA, Shanks III WC, Ridley WI (eds) Applications in Microanalytical Techniques to Understanding Mineralizing Processes. Reviews in Economic Geology 7: 1-35

Zeh A, Brätz H, Millar IL, Williams IS (2001) A combined zircon SHRIMP and Sm-Nd isotope study on high-grade paragneisses from the Mid-German Crystalline Rise: evidence for northern Gondwana and Grenvillean provenance. J Geol Soc, London 158: 983-994

ZEN E-AN (1988) Phase relations of peraluminous granitic rocks and their petrogenetic implications. Ann Rev Earth Planet Sci 16: 21-51

Żelaźniewicz A, Nowak I, Achramowicz S, Czapliński W (2003) The northern part of the Izera-Karkonosze block: a passive margin of the Saxothuringian Terrane. In: CiężKowski W, Wojewoda J, ŻElaźniewicz A (eds) Western Sudetes: From Vendian to Quaternary. Wind, Wrocław, pp 17-32 (in Polish with English summary)

Żelaźniewicz A, Dörr W, Bylina P, Franke W, HaAck U, Heinisch H, Schastok J, Grandmontagne K, Kulicki C (2004) The eastern continuation of the Cadomian orogeny: U-Pb zircon evidence from Saxo-Thuringian granitoids in south-western Poland and northern Czech Republic. Int J Earth 93: 773-781

Żelaźniewicz A, Fanning CM, Achramowicz S (2009) Refining the granite, gneiss and schist interrelationships within the Lusatian-Izera Massif, West Sudetes, using SHRIMP U-Pb zircon analyses and new geologic data. Geol Sudetica 41: 67-84

ŻElaźniewicz A, Aleksandrowski P, BuŁa Z, Karnkowski PH, Konon A, Oszczypko N, Ślączka A, ŻABA J, ŻytKo K (2011) Tectonic Subdivision of Poland. Komitet Nauk Geologicznych PAN, Wrocław, pp 1-60 (in Polish) 